Бондарєва Т. Г., к.е.н., доцент (Національний університет водного господарства та природокористування, м. Рівне), Немкович О. Б., к.е.н. (Відокремлений структурний підрозділ «Рівненський коледж Національного університету біоресурсів і природокористування України» м. Рівне, Україна)

\title{
ОБЛІКОВО-АНАЛІТИЧНИЙ АСПЕКТ УПРАВЛІННЯ БІОЛОГІЧНИМИ АКТИВАМИ В СІЛЬСЬКОГОСПОДАРСЬКИХ ПІДПРИЕМСТВАХ
}

У статті досліджено економічну сутність біологічних активів та удосконалено їх класифікацію. Розглянуто зміни щодо ведення обліку біологічних активів в частині довгострокових біологічних активів рослинництва. Удосконалено методичні підходи до аналізу біологічних активів. Запропоновано систему показників, що характеризують ефективність використання біологічних активів.

Ключові слова: облік, аналіз, біологічні активи, класифікація, плодоносні рослини.

Постановка проблеми в загальному вигляді. Створення конкурентоспроможної аграрної економіки України потребує приділення значної уваги питанням управління біологічними активами, які $\epsilon$ специфічним засобом сільськогосподарського виробництва та відіграють важливу роль у забезпеченні розвитку економіки в цілому та аграрного сектора зокрема. Згідно даних Державної служби статистики України станом на 01.01.2018 р. вартість біологічних активів підприємств сільського, лісового та рибного господарства становила 28921,0 млн грн., що складало 3,2\% усіх активів. 3 них 10472,5 млн грн. або 36,2\% становили довгострокові біологічні активи та 18448,5 млн грн. або 63,8\% - поточні біологічні активи [1]. У порівнянні з попереднім звітним періодом темпи росту біологічних активів склали $111,5 \%$, а їх частка у загальній структурі активів зросла майже вдвічі. Разом з тим у сучасних умовах господарювання на більшості вітчизняних аграрних підприємств спостерігаються негативні тенденції до зниження ефективності управління даним видом активів. Зважаючи на це, актуальними залишаються проблеми обліку та аналізу біологічних активів як важливих інструментів формування масиву інформації для потреб управління сільськогосподарським виробництвом.

Аналіз останніх досліджень і публікацій. Вирішенню питань 
обліково-аналітичних засад управління біологічними активами присвячені дослідження М.Т. Білухи, Ф.Ф. Бутинця, О.Д. Гудзинського, М.Я. Дем'яненка, В.А. Дерія, В.М. Жука, О.О. Канцурова, Г.Г. Кірейцева, Н.М. Малюги, В.Ф. Мниха, М.Ф. Огійчука, Н.Л. Правдюк, В.К. Савчука, П.Т. Саблука, Л.К. Сука, В.О. Шевчука та інших вчених. Проте постійні зміни у нормативних документах з бухгалтерського обліку диктують потребу в удосконаленні обліково-аналітичного забезпечення управління біологічними активами сільськогосподарських підприємСТВ.

Формулювання цілей статті. Розглянути зміни щодо ведення обліку біологічних активів в частині довгострокових біологічних активів рослинництва сільськогосподарських підприємств та удосконалити методичні підходи до аналізу біологічних активів шляхом розробки системи показників, що характеризують ефективність використання біологічних активів.

Виклад основного матеріалу дослідження. Для ефективного інформаційного забезпечення зовнішніх і внутрішніх користувачів, підвищення якості та об'єктивності бухгалтерської інформації важливим $€$ дослідження, що спрямоване на вдосконалення та розробку методичних підходів щодо організації та ведення обліку біологічних активів у сільськогосподарських підприємствах.

За результатами дослідження поняття біологічних активів можна зробити висновок, що ця категорія $є$ однією з найважливіших у господарській діяльності сільськогосподарських підприємств.

У Положенні (стандарті) бухгалтерського обліку 30 «Біологічні активи» запропоновано таке визначення: «Біологічний актив - тварина або рослина, яка в процесі біологічних перетворень здатна давати сільськогосподарську продукцію та/або додаткові біологічні активи, а також приносити в інший спосіб економічні вигоди» [2]. Схоже визначення даного об'єкту обліку містить і Національне положення (стандарт) бухгалтерського обліку в державному секторі 136 «Біологічні активи»: «біологічний актив - тварина або рослина, яка в процесі біологічних перетворень здатна давати сільськогосподарську продукцію та/або додаткові біологічні активи, а також в інший спосіб сприяє економічним вигодам». Відповідно до Міжнародного стандарту бухгалтерського обліку 41 «Сільське господарство» «біологічний актив - це жива тварина або рослина» [3].

У сучасній літературі економічного характеру більшість вчених трактують біологічні активи як живі істоти, організми, явище життя, біологічні ресурси. Проте єдиний підхід до трактування сутності біологічних активів відсутній.

Одним із методів пізнання, дослідження, вивчення об'єктів чи явищ $\epsilon$ їх класифікація, тобто поділ на класи на основі визначених загальних ознак об'єктів і закономірностей зв'язків між ними. Чим 
більше виділено ознак класифікації, тим вищий ступінь пізнання об'єкта. Від того, наскільки правильно визначено класифікаційні ознаки об'єкта, залежить порядок його обліку [4, С. 34].

На рис. 1 подано класифікацію біологічних активів з виділенням найважливіших класифікаційних ознак.

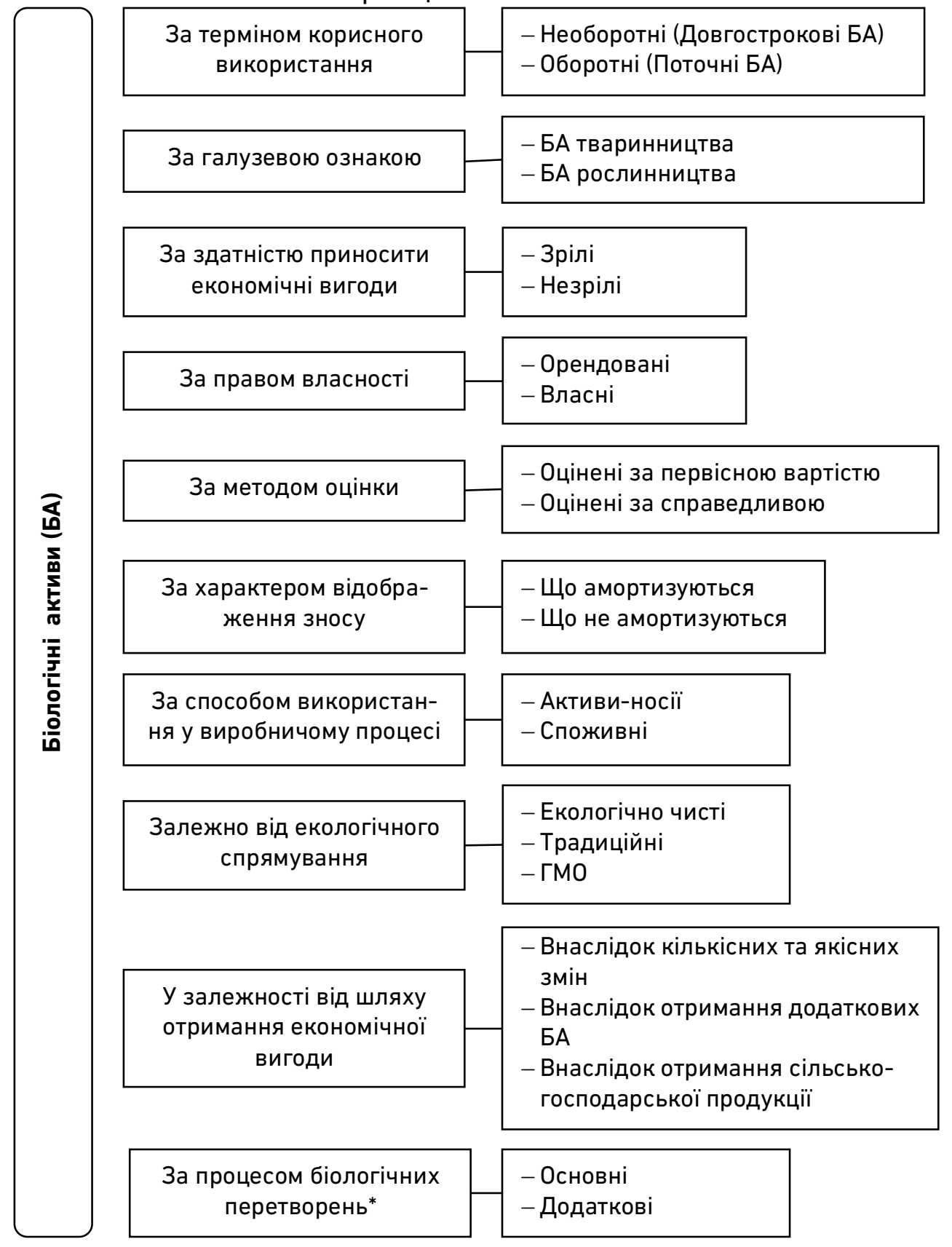

Рис. 1. Узагальнена класифікація біологічних активів [2-7] *Доповнено авторами 
У бухгалтерському обліку досить поширеною $є$ класифікація біологічних активів за терміном корисного використання, за галузевою ознакою та за методом оцінки. Така класифікація передбачена Методичними рекомендаціями з бухгалтерського обліку біологічних активів.

Пропонується доповнити існуючу класифікацію біологічних активів класифікаційною ознакою - за процесом біологічних перетворень. За процесом біологічних перетворень біологічні активи можна поділити на основні та додаткові. У тваринництві, наприклад, основними $€$ тварини основного стада, тобто продуктивні тварини, які систематично надають сільськогосподарську продукцію та/або додаткові біологічні активи. Додаткові ж біологічні активи - це біологічні активи, одержані в процесі біологічних перетворень. До них відносять приплід. У бджільництві основними є сім'ї бджіл, а додатковими нові рої, у риборозведенні, відповідно, риба та матеріал для розведення риби. У рослинництві прикладом основних біологічних активів можуть бути виноградники, а додатковими - чубуки.

Розробка наукової проблематики щодо трактування економічної сутності біологічних активів та їх класифікації сприяє створенню теоретичних основ досліджуваного напряму 3 широким розглядом практичних аспектів. Дане питання потребує більш ґрунтовного дослідження, оскільки це дає змогу правильно організувати аналітичний і синтетичний облік біологічних активів та сприяє повному розкриттю інформації про їх наявність та рух.

Сільськогосподарські підприємства облік біологічних активів ведуть на рахунках 21 «Поточні біологічні активи» та 16 «Довгострокові біологічні активи». Однак, варто зазначити, що з 05.01.2018 p. Міністерство фінансів України, наказом від 12.12.2017 р. № 1019 , внесло зміни до окремих нормативів з бухгалтерського обліку, які вплинули на облік довгострокових біологічних активів рослинництва.

Так П(С)БО 30 «Біологічні активи» доповнено новим терміном «плодоносні рослини», який має таке значення - довгострокові біологічні активи, які використовуються у процесі виробництва сільськогосподарської продукції та систематично надають сільськогосподарську продукцію та/або додаткові біологічні активи. До плодоносних рослин відносять виноградники і сади.

Крім того, у П(С)БО 7 «Основні засоби» група основних засобів «Багаторічні насадження» перейменована в «Багаторічні насадження і плодоносні рослини».

Тепер облік плодоносних рослин, пов'язаних із сільськогосподарською діяльністю, ведеться на субрахунку 108 «Багаторічні наса- 
дження» рахунку 10 «Основні засоби». А на рахунку 16 «Довгострокові біологічні активи» обліковується й узагальнюється інформація про наявність та рух власних або отриманих на умовах фінансової оренди довгострокових біологічних активів, крім плодоносних рослин, які обліковуються на рахунку 10 «Основні засоби».

Зважаючи на це, з метою методично правильного обліку плодоносних рослин, сільськогосподарським підприємствам необхідно ретельно підійти до вибору системи рахунків для відображення сукупності однорідних господарських операцій з обліку витрат з моменту посадки до досягнення плодоносного віку, зарахування до складу активів, нарахування амортизації.

Варто зауважити, що недосконала методика обліку біологічних активів знижує рівень достовірності інформації, яка використовується системою аналізу, і відповідно понижує якість управлінських рішень у менеджменті. Основні методичні підходи до аналізу біологічних активів у сільськогосподарських підприємствах подані на рис. 2.

Виходячи із зазначених підходів та з метою розв'язання конкретних завдань управління, можна виділити такі основні напрями аналізу біологічних активів підприємства:

- визначення питомої ваги біологічних активів в загальній сумі оборотних активів;

- оцінка складу і структури біологічних активів;

- аналіз основних тенденцій розвитку;

- визначення ефективності використання біологічних активів і факторів, які впливають на неї;

- розрахунок та вивчення ступеня впливу основних факторів на величину біологічних активів;

- виявлення резервів підвищення ефективності використання біологічних активів підприємства;

- надання вичерпної інформації для прийняття управлінських рішень.

Зважаючи на те, що у сучасних умовах господарювання більшість сільськогосподарських підприємств не спроможні залучити додаткові ресурси через обмежені фінансові можливості, одним із способів зростання прибутку для них $є$ підвищення ефективності використання наявних ресурсів. У цьому аспекті у процесі аналізу більш детального вивчення потребують питання оцінювання ефективності використання біологічних активів.

Необхідно відмітити, що ефективність використання біологічних активів характеризується системою показників, які пропонуємо умовно розділити на дві групи: показники ефективності відтворення біо- 
логічних активів та показники ефективності використання біологічних активів.

\begin{tabular}{|c|}
\hline АНАЛІЗ БІОЛОГІЧНИХ АКТИВІВ \\
\hline Мета аналізу біологічних активів \\
\hline $\begin{array}{l}\text { оцінювання стану, структури та динаміки біологічних активів, ви- } \\
\text { значення забезпеченості підприємства ними та пошуку резервів } \\
\text { раціонального їх використання }\end{array}$ \\
\hline Завдання аналізу біологічних активів \\
\hline $\begin{array}{l}\text { виявлення змін у складі та структурі біологічних активів в дина- } \\
\text { міці; } \\
\text { виявлення впливу факторів на досліджувані показники та їх не- } \\
\text { гативну зміну; } \\
\text { в виявлення резервів підвищення ефективності використання біо- } \\
\text { логічних активів; } \\
\text { > розробка управлінських рішень та їх реалізація }\end{array}$ \\
\hline Об'єкти аналізу біологічних активів \\
\hline $\begin{array}{l}>\text { поточні біологічні активи рослинництва; } \\
\text { поточні біологічні активи тваринництва; } \\
>\text { довгострокові біологічні активи рослинництва; } \\
\text { д довгострокові біологічні активи; } \\
>\text { незрілі біологічні активи }\end{array}$ \\
\hline Види аналізу біологічних активів \\
\hline $\begin{array}{l}\text { порівняльний (виробничий, маржинальний, фінансовий, страте- } \\
\text { гічний); } \\
>\text { факторний аналіз (детермінований, стохастичний); }\end{array}$ \\
\hline Основні етапи аналізу біологічних активів \\
\hline $\begin{array}{l}>\text { визначення цілей, що повинні переслідуватись у процесі аналізу; } \\
\text { обрання методів, прийомів і способів аналізу біологічних активів; } \\
\text { вибір джерел інформації та систематизація отриманих даних; } \\
\text { >аналіз складу та структури біологічних активів в динаміці; } \\
\text { >аналіз біологічних активів у розрізі окремих видів; } \\
\text { розрахунок та оцінка показників ефективності використання бі- } \\
\text { ологічних активів; } \\
\text { проведення факторного аналізу показників ділової активності; } \\
\text { визначення частки вартості біологічних активів підприєства у } \\
\text { вартості біологічних активів галузі, регіону, країни в цілому; } \\
\text { узагальнення результатів аналізу, розробка висновків і пропо- } \\
\text { зицій, розробка організаційно-технічних заходів щодо усунення } \\
\text { недоліків }\end{array}$ \\
\hline
\end{tabular}

Рис. 2. Методичні підходи до аналізу біологічних активів 
У групі показників оцінювання відтворення біологічних активів найбільш суттєвими є:

- коефіцієнт надходження довгострокових біологічних активів показує частку вартості довгострокових біологічних активів, що надійшли за відповідний період, у загальній їх вартості. Його обчислюють як відношення обсягу надходження довгострокових біологічних активів за період, що аналізується до вартості довгострокових біологічних активів на кінець цього періоду.

- коефіцієнт вибуття довгострокових біологічних активів - показує частку вартості довгострокових біологічних активів, які вибули за період, що аналізується, в загальній вартості довгострокових біологічних активів на початок цього періоду. Його розраховують як відношення вартості довгострокових біологічних активів, які вибули за період, що аналізується, до вартості довгострокових біологічних активів на початок цього періоду.

- коефіцієнт приросту довгострокових біологічних активів - характеризує приріст довгострокових біологічних активів. Його обчислюють як відношення різниці довгострокових біологічних активів, які надійшли та які вибули за період, що аналізується, до вартості довгострокових біологічних активів на початок цього періоду (табл. 1).

Ефективність використання біологічних активів пропонуємо оцінювати за системою показників, основним серед яких є коефіцієнт виробничої віддачі довгострокових біологічних активів. Цей коефіцієнт відображає дохідність використання даного виду активів і обчислюється як відношення чистого доходу від реалізації продукції за період, що аналізується, до середньої вартості довгострокових біологічних активів за цей період.

Коефіцієнт виробничої місткості довгострокових біологічних активів - величина, обернена до коефіцієнту виробничої віддачі довгострокових біологічних активів. Вона характеризує середню вартість довгострокових біологічних активів, що припадає на одну гривню чистого доходу від реалізації продукції, і розраховується як відношення середньої вартості довгострокових біологічних активів за період, що аналізується, до чистого доходу від реалізації продукції за цей період.

Для аналізу ефективності біологічних активів може застосовуватися також показник рентабельності біологічних активів (відношення чистого прибутку підприємства до середньорічної вартості його біологічних активів). 
Показники відтворення біологічних активів

\begin{tabular}{|c|c|c|}
\hline Показник & $\begin{array}{c}\text { Розрахункова форму- } \\
\text { ла }\end{array}$ & Умовні позначення \\
\hline $\begin{array}{l}\text { 1. Коефіцієнт на- } \\
\text { дходження дов- } \\
\text { гострокових біо- } \\
\text { логічних активів }\end{array}$ & 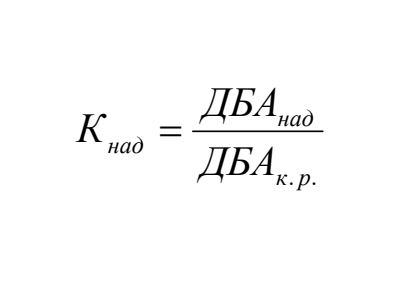 & $\begin{array}{l}\text { ДБА } A_{\text {над }} \text { довгострокові біоло- } \\
\text { гічні активи, що надійшли за } \\
\text { певний період; } \\
\text { ДБА } A_{\text {к.. }}-\text { вартість довгостро- } \\
\text { кових біологічних активів на } \\
\text { кінець року }\end{array}$ \\
\hline $\begin{array}{l}\text { 2. Коефіцієнт } \\
\text { вибуття довго- } \\
\text { строкових біоло- } \\
\text { гічних активів }\end{array}$ & $K_{\text {виб }}=\frac{Д Б A_{\text {виб }}}{Д Б A_{n . p .}}$ & $\begin{array}{l}\text { ДБА виб - довгострокові біоло- } \\
\text { гічні активи, що вибули за } \\
\text { певний період; } \\
\text { ДБА } A_{\text {п.р. }}-\text { вартість довгостро- } \\
\text { кових біологічних активів на } \\
\text { початок року }\end{array}$ \\
\hline $\begin{array}{l}\text { 3. Коефіцієнт } \\
\text { приросту довго- } \\
\text { строкових біоло- } \\
\text { гічних активів }\end{array}$ & $K_{n p}=\frac{Д Б A_{\text {над }}-Д Б A_{\text {виб }}}{Д Б A_{n . p .}}$ & $\begin{array}{l}\text { ДБА } A_{\text {над }} \text { довгострокові біоло- } \\
\text { гічні активи, що надійшли за } \\
\text { певний період; } \\
\text { ДБА виб - довгострокові біоло- } \\
\text { гічні активи, що вибули за } \\
\text { певний період; } \\
\text { ДБА } A_{\text {п.р. }} \text { - вартість довгостро- } \\
\text { кових біологічних активів на } \\
\text { початок року }\end{array}$ \\
\hline
\end{tabular}

Важливою характеристикою ефективності використання біологічних активів $є$ коефіцієнт оборотності поточних біологічних активів, який показує швидкість їх обороту, або іншими словами, скільки разів у середньому поповнювалися поточні біологічні активи протягом звітного періоду.

Період обороту поточних біологічних активів показує, скільки днів потрібно для того, щоб поточний біологічний актив був реалізований. Позитивна динаміка даного показника до зменшення (табл. 2). 
Таблиця 2

Показники ефективності використання біологічних активів

\begin{tabular}{|c|c|c|}
\hline Показник & $\begin{array}{c}\text { Розрахункова фор- } \\
\text { мула }\end{array}$ & Умовні позначення \\
\hline 2 & 3 & 4 \\
\hline $\begin{array}{l}\text { 1. Коефіцієнт ви- } \\
\text { робничої віддачі } \\
\text { довгострокових } \\
\text { біологічних акти- } \\
\text { вів }\end{array}$ & $K_{\text {sid }}=\frac{\text { ЧД }}{\overline{Д Б А}}$ & $\begin{array}{l}\text { ЧД - чистий дохід від } \\
\text { реалізації продукції, то- } \\
\text { варів, робіт, послуг; } \\
\text { ДБА - середньорічна } \\
\text { вартість довгострокових } \\
\text { біологічних активів }\end{array}$ \\
\hline $\begin{array}{l}\text { 2. Коефіцієнт ви- } \\
\text { робничої місткості } \\
\text { довгострокових } \\
\text { біологічних акти- } \\
\text { вів }\end{array}$ & $K_{\text {мicm }}=\frac{\overline{Д Б A}}{\text { ЧД }}$ & $\begin{array}{l}\overline{Д Б А ~-~ с е р е д н ь о р і ч н а ~} \\
\text { вартість довгострокових } \\
\text { біологічних активів; } \\
\text { чД - чистий дохід від } \\
\text { реалізації продукції, то- } \\
\text { варів, робіт, послуг }\end{array}$ \\
\hline $\begin{array}{l}\text { 3. Рентабельність } \\
\text { біологічних акти- } \\
\text { вів }\end{array}$ & $P^{5 A}=\frac{4 \Pi}{\overline{Б A}} \times 100 \%$ & $\begin{array}{l}\text { ЧП - чистий прибуток; } \\
\overline{Б A} \text { - середньорічна ва- } \\
\text { ртість біологічних акти- } \\
\text { вів }\end{array}$ \\
\hline $\begin{array}{l}\text { 4. Коефіцієнт обо- } \\
\text { ротності поточних } \\
\text { біологічних акти- } \\
\text { вів }\end{array}$ & $K_{o \bar{\sigma}}^{5 A}=\frac{\text { ЧД }}{\overline{\Pi Б А}}$ & $\begin{array}{l}\text { ЧД - чистий дохід від } \\
\text { реалізації продукції, то- } \\
\text { варів, робіт, послуг; } \\
\text { ПБА - середньорічна } \\
\text { вартість поточних біоло- } \\
\text { гічних активів }\end{array}$ \\
\hline $\begin{array}{l}\text { 5. Період обороту } \\
\text { поточних біологіч- } \\
\text { них активів }\end{array}$ & $\Pi_{o \sigma}^{5 A}=\frac{\overline{\Pi Б A \times 365}}{\text { ЧД }}$ & $\begin{array}{l}\overline{\Pi Б А} \text { - середньорічна } \\
\text { вартість поточних біоло- } \\
\text { гічних активів; } \\
\text { ЧД - чистий дохід від } \\
\text { реалізації продукції }\end{array}$ \\
\hline
\end{tabular}

Вважаємо, що запропонована система показників дасть можливість управлінському персоналу об'єктивно оцінити оптимальність використання біологічних активів та оперативно відреагувати на негативні тенденції, зосередивши увагу на тих факторах, які мають найбільш суттєвий вплив на ефективність використання даного виду активів.

Висновки. Досконала методика обліку біологічних активів під- 
вищує рівень достовірності інформації, яка використовується системою аналізу, і відповідно підвищує якість управлінських рішень у менеджменті. Водночас якісно проведений аналіз біологічних активів дасть можливість забезпечити своєчасне їх оновлення і вирішити проблему підвищення ефективності використання.

1. Діяльність суб'єктів господарювання за 2017 рік : статистичний збірник. Державна служба статистики України / ред. М. С. Кузнецової. К. : ТОВ «Видавництво «Консультант», 2018. 146 с. 2. Положення (стандарт) бухгалтерського обліку 30 «Біологічні активи» : наказ Міністерства фінансів України від 18.11.05p. № 790. URL: http://zakon.rada.gov.ua. (дата звернення: 15.01.2019). 3. Міжнародний стандарт бухгалтерського обліку 41 «Сільське господарство» IASB; Стандарт, Міжнародний документ від 01.01.2012. URL: http://zakon2.rada.gov.ua/laws/show/929_027. (дата звернення: 15.01.2019). 4. Кузьмович П. М. Поняття біологічних активів та їх класифікація. Облік і фінанси АПК. 2010. №4. С. 32-37. 5. Циган Р. М., Костюк О. С., Тимченко Є. А. Удосконалення класифікації біологічних активів з метою підвищення ефективності обліково-аналітичної роботи підприємства. Ефективна економіка. 2012. No 1. URL: http://www.economy.nayka.com.ua (дата звернення: 15.01.2019). 6. Кучеренко Т. Є. Відображення біологічних активів у фінансовій звітності сільськогосподарських підприємств. Бухгалтерський облік і аудит. 2007. № 7. С. 46-49. 7. Мельник О. С. Біологічні активи та біологічні перетворення рибництва: економічна сутність і класифікація. Економіка. Фінанси. Менеджмент : актуальні питання науки і практики. 2017. № 2. C. 114-124. URL: http://efm.vsau.org/files/pdfa/3475.pdf (дата звернення: 15.01.2019).

\section{REFERENCES:}

1. Diialnist subiektiv hospodariuvannia za 2017 rik : statystychnyi zbirnyk. Derzhavna sluzhba statystyky Ukrainy / red. M. S. Kuznetsovoi. K. : TOV «Vydavnytstvo «Konsultant», 2018. 146 s. 2. Polozhennia (standart) bukhhalterskoho obliku 30 «Biolohichni aktyvy»: nakaz Ministerstva finansiv Ukrainy vid 18.11.05r. № 790. URL: http://zakon.rada.gov.ua. (data zvernennia: 15.01.2019). 3. Mizhnarodnyi standart bukhhalterskoho obliku 41 «Silske hospodarstvo» IASB; Standart, Mizhnarodnyi dokument vid 01.01.2012. URL: http://zakon2.rada.gov.ua/laws/show/929_027. (data zvernennia: 15.01.2019). 4. Kuzmovych P. M. Poniattia biolohichnykh aktyviv ta yikh klasyfikatsiia. Oblik $i$ finansy APK. 2010. №4. S. 32-37. 5. Tsyhan R. M., Kostiuk 0. S., Tymchenko Ye. A. Udoskonalennia klasyfikatsii biolohichnykh aktyviv z metoiu pidvyshchennia efektyvnosti oblikovo-analitychnoi roboty pidpryiemstva. Efektyvna ekonomika. 2012. No 1. URL: http://www.economy.nayka.com.ua (data zvernennia: 15.01.2019). 6. Kucherenko T. Ye. Vidobrazhennia biolohichnykh aktyviv u finansovii zvitnosti silskohospodarskykh pidpryiemstv. Bukhhalterskyi oblik i audyt. 2007. № 7. S. 46-49. 7. Melnyk 0. S. Biolohichni aktyvy ta biolohichni 
peretvorennia rybnytstva: ekonomichna sutnist i klasyfikatsiia. Ekonomika. Finansy. Menedzhment : aktualni pytannia nauky i praktyky. 2017. № 2. S. 114124. URL: http://efm.vsau.org/files/pdfa/3475.pdf (data zvernennia: 15.01.2019).

Рецензент: д.е.н., доцент Осадча О. О. (НУВГП)

Bondarieva T. H., Candidate of Economics (Ph.D.), Associate Professor (National University of Water and Environmental Engineering, Rivne), Nemkovych O. B., Candidate of Economics (Ph.D.), Associate Professor (Rivne College of National University of Life and Environmental Sciences of Ukraine, Rivne)

\section{ACCOUNTING AND ANALYTICAL ASPECT OF BIOLOGICAL ASSETS MANAGEMENT OF AGRICULTURAL ENTERPRISES}

This article is devoted to the research of actual problems of the accounting methodology improvement of biological assets. The meaning of «biological assets» in normative acts and economic literature is revealed. It is proved that this category is one of the most important in the economic activity of the agricultural enterprises. The following article summarizes the classification of biological assets according to the literary sources. The classification of biological assets in terms of useful life, by the industry and by the valuation method is quite common in the accounting. A special classification feature is the approach to the valuation of biological assets, which is conditioned to the availability of two different evaluation options - the fair value and the initial cost. The authors offered to supplement the existing classification of biological assets by the classification mark - the process of biological transformations. In the process of biological transformations, biological assets can be divided into main and secondary ones.

The changes in the biological assets accounting for the 2018th are investigated. Currently, the accounting of the fruit-bearing plants related to the agricultural activity is conducted on the sub-account 108 «Perennial plantings» of the account 10 «Fixed assets». In the account 16 «Long-term biological assets», the information about the availability and movement of own or obtained on the terms of financial lease of the long-term biological assets, except for the fruit-bearing plants, which are recorded in the account 10 «Fixed assets» is recorded and summarized. 
The basic methodical approaches to the analysis of biological assets in agricultural enterprises are reviewed. A system of indicators defining the efficiency of the biological assets usage is offered, namely: the coefficient of long-term biological assets inflow; the longterm biological asset retirement factor; the coefficient of the longterm biological assets growth; the coefficient of production efficiency of the long-term biological assets; the coefficient of production capacity of the long-term biological assets; the profitability of biological assets; the turnover rate of current biological assets; the period of the current biological assets turnover. Keywords: accounting, analysis, biological assets, classification, fruiting plants.

Бондарева Т. Г., к.э.н., доцент (Национальный университет водного хозяйства и природопользования, г. Ровно), Немкович О. Б., к.э.н. (Обособленное структурное подразделение «Ровенский колледж Национального университета биоресурсов и природопользования Украины», г. Ровно)

\section{УЧЕТНО-АНАЛИТИЧЕСКИЙ АСПЕКТ УПРАВЛЕНИЯ БИОЛОГИЧЕСКИМИ АКТИВАМИ В СЕЛЬСКОХОЗЯЙСТВЕННЫХ ПРЕДПРИЯТИЯХ}

В статье исследовано экономическую сущность биологических активов и усовершенствована их классификация. Рассмотрены изменения по ведению учета биологических активов в части долгосрочных биологических активов растениеводства. Усовершенствованы методические подходы к анализу биологических активов. Разработана система показателей, характеризующих эффективность использования биологических активов.

Ключевые слова: учет, анализ, биологические активы, классификация, плодоносящие растения. 